\title{
AUTORADIOGRAPHIC DETECTION OF DIAMINE INHIBITION OF MAMMALIAN SPERM MATURATION
}

\author{
J. D. HUNTER AND ELIZABETH MANNING \\ Department of Biological Sciences, \\ The University of Texas at El Paso, El Paso, Texas
}

(Received 26th April 1973)

Dichloroacetyl-diamine compounds, derived originally from chloramphenicol antibiotics, possess selective and reversible actions in curtailing spermatogenesis in mammals without major pathological effects on other tissues (Jackson, 1966; Reddy \& Svoboda, 1967; Debeljuk, Arimura \& Schally, 1973). In this study, liquid emulsion autoradiography (ARG) was used to measure the incorporation of tritiated thymidine into the DNA of primary spermatocytes and spermatogonia to note if orally administered bis-diamine could alter DNA synthesis as well as the duration of sperm maturation in the mouse.

Ninety-day-old Charles-River CD-1 male mice were grouped as outlined in Table 1. Treated mice received measured amounts of Win 18,446-N, $\mathrm{N}^{\prime}$ bis-(dichloroacetyl)-1,8 octamethylene-diamine (Sterling-Winthrop) in pulverized Wayne Lab Blox using $1 \%$ Tragacanth Gum to suspend the insoluble drug. Control mice received an identical mixture minus diamine. The mixture was moulded into cubes and dried. All mice consumed an average of $5 \mathrm{~g} /$ mouse/day for the treatment durations noted in Table 1 . At $72 \mathrm{hr}$ before autopsy, $1 \mu \mathrm{Ci}\left[{ }^{3} \mathrm{H}\right]$ thymidine/g body weight was injected subcutaneously to label germinal cell DNA. Testes and epididymides were then weighed, placed in Bouin's fixative and embedded in paraffin wax. Mid-sections were prepared by ARG using Kodak NTB2 and were stained with haematoxylin or periodic acid-Schiff (PAS) reagent (Clermont \& Trott, 1969). All seminiferous tubule cross-sections from single testis sections of each mouse were counted; the percentage containing two or more primary spermatocyte nuclei with at least 5 grains per nucleus was recorded and the total numbers of labelled spermatocytes per tubule from any five labelled tubules were averaged. The density of grains over labelled tubule nuclei was arbitrarily classified as 'heavy' (20 or more grains/nucleus), 'medium' (10 to 19 grains) and 'low' (5 to 9 grains) and the percentage of each class was recorded (Table 1).

During the initial 10 days of diamine ingestion, there was no whole weight decline in the testes but after 21 days, a highly significant $(P<0.001)$ weight loss was recorded in treated mice (Table 1 ). Some weight reduction was observed even after recovery of spermatogenesis.

Analysis of ARG indicated a reduction in the percentage of labelled tubules with some temporary increase in nuclear grain density after 10 days of diamine 


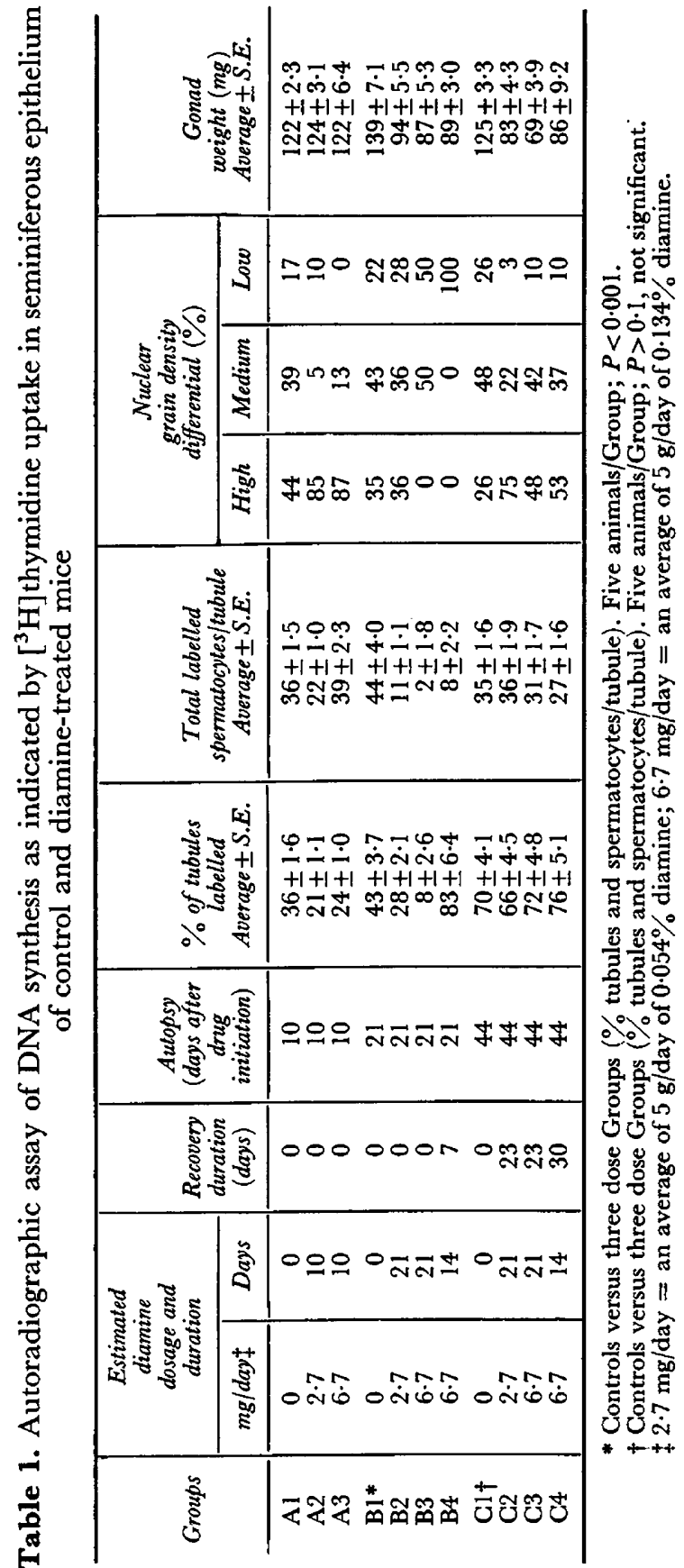


treatment. After 3 weeks treatment (Groups B2 and B3), a significant decrease occurred in the $\%$ of tubules labelled and in the number of labelled spermatocytes/tubule. Decreased spermatocyte grain density, especially in Group B3, indicated an increase in S-phase duration in cells before meiosis. The most common cell types found in these tubules were spermatids in various stages of spermiogenesis. None was labelled as such cells have no $S$ phase. Tubules had numerous dead cells, especially degenerating multinucleate spermatids. Treated B2 and B3 testes were devoid of mature spermatozoa in both seminiferous tubules and epididymides, indicating inhibition of spermiogenesis.

Animals of Group B4, treated for 2 weeks and allowed a 1-week recovery period, showed a marked increase in the percentage of labelled tubules containing spermatocytes of low grain density. Mice of Groups C2 to 4, allowed 23 to 30 days' recovery, showed a further increase in thymidine uptake indicated by higher nuclear grain densities. The surviving germinal cells during this recovery period showed heightened DNA synthesis, and possibly shortened $\mathrm{S}$ phase, indicated by increased nuclear grain density. These mice showed no significant differences from controls in labelled cell populations, but controls did contain a much greater abundance of unlabelled seminiferous epithelium and higher organ weights. Ten males of Group C3 type were tested for fertility by placing with females of proven fecundity. None conceived. After a 50-day recovery period, however, fertility was restored and normal offspring were produced.

In a second study, ARG was used to measure the sequence of labelled germinal cell maturation in treated and control mice to detect the stages of spermatogenesis and maturation most susceptible to diamine alteration. A control group of sixteen 90 -day-old males received only $\left[{ }^{3} \mathrm{H}\right] \mathrm{TdR}$. A second group of sixteen received $\left[{ }^{3} \mathrm{H}\right]$ thymidine $4 \mathrm{hr}$ before a 21 -day duration of $6.7 \mathrm{mg}$ bis-diamine daily in their diet. Primary spermatocytes and spermatogonia in $\mathrm{S}$ phase were labelled within an hour after injection. Diamine given after labelling had no effect on the numbers of labelled nuclei nor on the percentage of labelled tubules. Every 5 days for the next 20 days' differentiation time, four control and four diamine-treated males were killed and ARG of testes were prepared. Mid-sections were assayed and the latest or most mature stage of development of labelled germinal cells was identified.

In mice killed after 5 days' differentiation, early pachytene spermatocytes were the most mature labelled germinal cells (Table 2). After 15 days' differentiation, a marked increase in labelled type 7 spermatids was noted due to meiotic divisions, yet no difference was noted between control and treated cells. After 20 days, the most mature labelled cells in both groups were type 15 spermatids indicating no change in germinal maturation rate using ARG, morphology and PAS-staining reactions as criteria (Clermont \& Trott, 1969; Clermont, 1972). There was, however, a significant reduction $(P<0.001)$ in tubule germinal cell numbers indicated by spermatid cytolysis in treated gonads. Nuclear grain densities and the percentage of tubule nuclei labelled showed no differences between groups $(P>0 \cdot 1)$. Multinucleated giant cells were noted especially after 20 days of diamine treatment. Giant cells in which only a portion of the surface nuclei were labelled indicated possible fusion of 
separate labelled and unlabelled spermatids and failure to complete cytokinesis. In one treated group of mice allowed 25 days' differentiation (not tabulated), only occasional labelled spermatozoa were identified in the tubules and none in the epididymides. Due to marked spermatid degeneration, spermiogenesis was rarely completed after 20 days on diamine.

Marked increase in fighting behaviour occurred among diamine-treated males in contrast to controls in identical environments. Sterile males showed no reduction in libido. Approximately $3 \%$ of Leydig cells were labelled in both control and treated mice. Testosterone in sterile aggressive mice may have had

Table 2. Assay of the sequence of spermatogenic cell differentiation in control and diamine-treated mice from 5 to 20 days following $\left[{ }^{3} \mathrm{H}\right]$ thymidine labelling

\begin{tabular}{|c|c|c|c|c|c|c|}
\hline \multirow{2}{*}{$\begin{array}{l}\text { Differentiation } \\
\text { time after } \\
{\left[{ }^{3} H\right] \text { thymidine }} \\
\text { labelling }\end{array}$} & \multicolumn{2}{|c|}{$\begin{array}{l}\text { Latest cell stage labelled } \\
\quad \text { class, stage, type }\end{array}$} & \multicolumn{2}{|c|}{$\begin{array}{l}\text { Average no. of } \\
\text { cells/tubule* } \\
\quad \pm S . E .\end{array}$} & \multicolumn{2}{|c|}{$\begin{array}{c}\% \text { of cells labelledl } \\
\text { tubule } \\
\text { Average } \pm S . E .\end{array}$} \\
\hline & Control & $\begin{array}{l}\text { Diamine- } \\
\text { treated }\end{array}$ & Control & $\begin{array}{l}\text { Diamine- } \\
\text { treated }\end{array}$ & Control & $\begin{array}{l}\text { Diamine- } \\
\text { treated }\end{array}$ \\
\hline 5 days & $\begin{array}{l}\text { Early } \\
\text { pachytene } \\
\text { spermatocytes }\end{array}$ & $\begin{array}{l}\text { Early } \\
\text { pachytene } \\
\text { spermatocytes }\end{array}$ & $47 \pm 2 \cdot 8$ & $48 \pm 2 \cdot 7$ & $77 \pm 1 \cdot 8$ & $76 \pm 3 \cdot 0$ \\
\hline 10 days & $\begin{array}{l}\text { Late } \\
\text { pachytene } \\
\text { spermatocytes }\end{array}$ & $\begin{array}{l}\text { Late } \\
\text { pachytene } \\
\text { spermatocytes }\end{array}$ & $47 \pm 2 \cdot 4$ & $43 \pm 3 \cdot 0$ & $89 \pm 3 \cdot 2$ & $74 \pm 1 \cdot 2$ \\
\hline 15 days & $\begin{array}{l}\text { Spermatids } \\
\text { stage VII } \\
\text { type } 7\end{array}$ & $\begin{array}{l}\text { Spermatids } \\
\text { stage VII } \\
\text { type } 7\end{array}$ & $112 \pm 9 \cdot 3$ & $117 \pm 7 \cdot 9$ & $43 \pm 4 \cdot 9$ & $59 \pm 2 \cdot 0$ \\
\hline 20 days & $\begin{array}{l}\text { Spermatids } \\
\text { type } 15\end{array}$ & $\begin{array}{l}\text { Spermatids } \\
\text { type } 15 \\
\text { and giant cells }\end{array}$ & $76 \pm 3 \cdot 6$ & $19 \pm 7 \cdot 3$ & $24 \pm 27$ & $37 \pm 5 \cdot 3$ \\
\hline
\end{tabular}

* Average of five tubules per mouse with four mice per treatment group. Only the most mature cell types in a tubule were used in population estimates.

fewer spermatogenic targets and this may have given an enhanced neural effect (Sar \& Stumpf, 1973).

In conclusion, bis-diamine ingested over a 21-day period produced a significant reduction in the number of primary spermatocytes capable of DNA synthesis as well as a total reduction in the tubule germinal cell population. Both early premeiotic S-phase germinal cells and spermatids during maturation were inhibited. Within about 3 weeks after-treatment, DNA synthetic capability was restored and fertility recovered after 50 days, and possibly earlier. This study confirms that the duration of spermatogenesis comprises an 'all or none constant' for a given mammalian species with spermatid maturation particularly sensitive to chemical inhibition (Glermont \& Harvey, 1965; Clermont \& Trott, 1969; Steinberger, 1971; Clermont, 1972).

Thanks are due to the University Research Institute, Mr Robert Marc and Mrs Suzanne Hunter for financial and technical assistance, and the SterlingWinthrop Research Institute for supplying the drug. 


\section{REFERENCES}

Clermont, Y. (1972) Kinetics of spermatogenesis of mammals: seminiferous epithelium cycle and spermatogonial renewal. Physiol. Rev. 52, 198.

Clermont, Y. \& Harvey, S. C. (1965) Duration of the cycle of the seminiferous epithelium of normal, hypophysectomized and hypophysectomized-hormone treated albino rats. Endocrinology, 76, 80.

Clermont, Y. \& TROTT, M. (1969) Duration of the cycle of the seminiferous epithelium in the mouse and hamster determined by means of ${ }^{3} \mathrm{H}$-thymidine and radioautography. Fert. Steril. $20,805$.

Debeljuk, L., Arimura, A. \& Schally, A. V. (1973) Pituitary and serum FSH and LH levels after massive and selective depletion of the germinal epithelium in the rat testis. Endocrinology, 92, 48.

Jackson, H. (1966) Antifertility compounds in the male and female. Charles C. Thomas, Springfield, Illinois.

REDDY, K. J. \& SvoBodA, D. J. (1967) Alterations in the rat testes due to an antispermatogenic agent. Archs Path. 84, 376.

SAR, M. \& STUMPr, W. E. (1973) Autoradiographic localization of radioactivity in the rat brain after the injection of 1,2- ${ }^{3} \mathrm{H}$-testosterone. Endocrinology, 92, 251.

Steinberger, E. (1971) Hormonal control of mammalian spermatogenesis. Physiol. Rev. 51, 1. 